V. KARAN ${ }^{1}$

\title{
WAVELET TRANSFORM-BASED CLASSIFICATION OF ELECTROMYOGRAM SIGNALS USING AN ANOVA TECHNIQUE
}

\begin{abstract}
Received March 20, 2014
Wavelet analysis of surface electromyogram (sEMG) signals has been investigated. Methods to remove noise before processing and further analysis are rather significant for these signals. The sEMG signals were estimated with the following steps, first, the obtained signal was decomposed using wavelet transform; then, decomposed coefficients were analyzed by threshold methods, and, finally, reconstruction was performed. Comparison of the Daubechies wavelet family for effective removing noise from the recorded sEMGs was executed preciously. As was found, wavelet transform db4 performs denoising best among the aforesaid wavelet family. Results inferred that Daubechies wavelet families (db4) were more suitable for the analysis of sEMG signals related to different upper limb motions, and a classification accuracy of $88.90 \%$ was achieved. Then, a statistical technique (one-way repeated factorial analysis) for the experimental coefficient was done to investigate the class separability among different motions.
\end{abstract}

Keywords: electromyogram, wavelet, analysis of variance, denoising, classifier.

\section{INTRODUCTION}

In order to use surface electromyogram (sEMG) signals as a diagnostic tool or control signals, their features are often extracted before proceeding to the classification stage. Attempts are being made to improve signal processing and to obtain more information about the examined muscles; various techniques have been applied in classification and processing of sEMGs [1-3]. In order to predict properties of sEMGs corresponding to voluntary muscle contractions, various models have been developed [4].

Wavelet transform was been rather extensively used in the analysis of EEG, but it began to be studied with respect to EMG only since last decade [5,6], particularly in the engineering application such as the control of prosthetic devices. Our study was motivated by the fact that identification of a mother wavelet function is of the paramount significance since there is no universal mother wavelet applicable to all types of the signals [7]. We applied wavelet denoising technique to remove interference noise from the signals recorded from the biceps brachii and

${ }^{1}$ Department of Electrical and Instrumentation Engineering, Thapar University, Patiala, India.

Correspondence should be addressed to V. Karan

(e-mail: karan.una@gmail.com). triceps brachii muscles of the subjects performing voluntary contractions. The general wavelet-based denoising procedures were composed of three steps, decomposition, determination of denoising wavelet's detail coefficients, and reconstruction [8].

Different levels of mother wavelets (db2-db14) of the Daubechies family were extracted to obtain the useful resolution components from the sEMG signals. After removing the noise, time frequency domain analysis was introduced for analyzing the relation between voluntary contractions and sEMG signals. The most effective wavelet for sEMG denoising has been chosen by calculating the root mean square (RMS) and standard deviation (s.d.) values. The results showed that the wavelet function db4 works best among the used wavelets to remove noise from the sEMG signals. Our study presents the effects of mean frequency $(\mathrm{MnF})$ and median frequency (MdF) in the EMG analysis, especially during voluntary contraction for analyzing the EMG-muscle force relationship.

Further on, in order to analyze the effectiveness of sEMG signals for the muscles realizing independent motions, a statistical technique of analysis of the variance has been implemented, since it helps to identify the data pattern and to express these data in a way to highlight better their similarities and differences. 


\section{METHODS}

SEMG Signal Acquisition and Processing. Three adult volunteers were involved in the tests. Surface EMG signals were collected using a routine technique by noninvasive electrodes from the skin surface of the elbow joint-controlling arm muscles, $\mathrm{mm}$. biceps brachii and triceps brachii. A differential amplifier was used. After amplification, signals were filtered using the corresponding software and hardware blocks. In both cases, a high-pass cutoff frequency was $10 \mathrm{~Hz}$, while a low-pass cutoff frequency of $500 \mathrm{~Hz}$ was kept [9-11]. Myograms were recorded from the above-mentioned muscles at low, medium and high voluntary contractions under isometric conditions. The block diagram for the system is shown in Fig. 1.

Denoising Using Wavelet Analysis. Wavelet transform is a capable transform with a flexible resolution in both time and frequency domains. The principle of wavelet denoising [12, 13] consists of decomposing the signal by performing wavelet, applying suitable thresholds to the detail coefficients, zeroing all coefficients below their associated thresholds, and, finally, reconstructing the denoised signal based on the modified detail coefficients. The underlying model for the surface EMG signal, $f(n)$, is the superposition of the signal, $s(n)$, and noise, e(n),

$$
f(n)=s(n)+e(n)
$$

Once the signal is passed through wavelet decomposition, a threshold needs to be selected for estimation of the signal of interest, $s(n)$, from $f(n)$ by discarding the corrupting noise e(n).

Feature Extraction. As the sEMG signal is timeand force-dependent, and its amplitude varies randomly above and below zero values, the analysis becomes important in a way to define characteristic properties of the signal. A wide variety of features $[14,15]$ have been considered individually and in the group, representing both the sEMG amplitude and spectral content. So, feature extraction was done for interpretation of the recorded signal. All extracted features (s.d., variance, mean absolute value, etc.) have certain specific advantages, but the most commonly used technique for characterizing the power of the signal is the root mean square (RMS) value. This parameter gives the physical meaning of the signal, namely the real energy. Another frequency domain parameter, the median frequency $(\mathrm{MdF})$, is described as the frequency that divides the power contained in the signal into two equal halves. The next parameter, mean frequency $(\mathrm{MnF})$, is an average frequency that is calculated as the sum of products of the power spectrum and the frequency divided by the total sum of the power spectrum.

According to a few authors [16, 17], mathematical analysis has been done to investigate various parameters of the power spectral density, and the above-mentioned frequencies ( $\mathrm{MnF}$ and $\mathrm{MdF}$ ) were found to be most reliable. So, these techniques have been used in investigating the muscle force relationship.

\section{RESULTS}

Computer-Aided Analysis. In our study, the wavelet denoising-based analysis was performed by dividing the signal into two different types; low and high sEMG signals. The time and frequency domain analyses were done to analyze the relationship between myoelectric signals vs. different force levels developed by the human arm muscles. For this, an analytic study was initiated to investigate whether the relationship between the normalized sEMG signal vs. normalized force does exist, and whether it is dependent on the exercise level

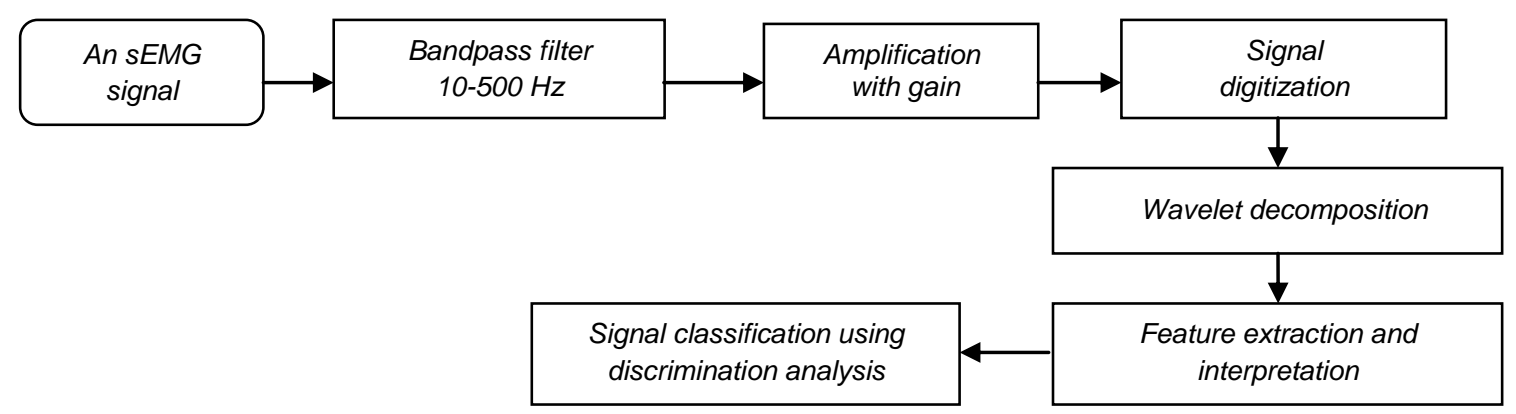

F i g. 1 Block diagram for the procedure of wavelet analysis of surface electromyogram signals.

Р и с. 1. Діаграма процедури вейвлет-аналізу сигналів поверхневої електроміограми. 
and the rate of force production. First, the raw sEMG signals for different muscle voluntary contractions were acquired and processed using classical filters and the wavelet transform approach. The processing of the signal included the following steps:

(i) Filtering the signal with band-pass filters $(10 \mathrm{~Hz}$ and $500 \mathrm{~Hz}$ ) updating the waveform graph cursors, to represent current values of the upper and lower cut-off frequencies.

(ii) Dual-channel spectral measurement on the prefiltered and filtered signals, to determine the frequency response of the filter.

(iii) Determination of different features (like RMS, s.d., energy of the signal, integrated EMG, and spectrogram). A front panel of the system is shown in Fig. 2.

Second, band-pass filtering and discrete wavelet transform (DWT) denoising of the sEMG signal were done. Different Daubechies wavelet functions (db2 to db14) were utilized for the extraction of different decomposition coefficients and for reconstruction of the signal. Comparative data of raw sEMG signals for three subjects with extracted features for different muscular contraction forces are show in Table 1. To describe the results of these wavelet features, various representatives for denoised RMS are presented in Table 2.

The raw sEMG signals were used to calculate the



T a b l e 1. Feature sets for different movement intensities (low - high); dependence on the position on the biceps (S1 - S3)

Т а б л и ц я 1. Набори ознак для рухових феноменів різної інтенсивності; залежність від положення на біцепсі

\begin{tabular}{l|c|c|c|c|c|c|c|c|c}
\hline \multirow{2}{*}{ Indices } & \multicolumn{3}{c}{ low } & \multicolumn{3}{c|}{ medium } & \multicolumn{3}{c}{ high } \\
\cline { 2 - 10 } & S1 & S2 & S3 & S1 & S2 & S3 & S1 & S2 & S3 \\
\hline RMS & 0.08 & 0.10 & 0.14 & 0.32 & 0.28 & 0.31 & 0.59 & 0.54 & 0.47 \\
MAV & 0.06 & 0.07 & 0.10 & 0.23 & 0.20 & 0.23 & 0.41 & 0.36 & 0.31 \\
VAR & 0.004 & 0.007 & 0.018 & 0.09 & 0.07 & 0.09 & 0.34 & 0.27 & 0.21 \\
s.d. & 0.06 & 0.08 & 0.13 & 0.31 & 0.27 & 0.30 & 0.58 & 0.52 & 0.46 \\
PSUM & 0.008 & 0.014 & 0.013 & 0.147 & 0.116 & 0.141 & 0.607 & 0.426 & 0.257 \\
\hline
\end{tabular}


T a b l e 2. Average RMSs of the Db family for different force levels (three subjects)

T а б л и ц я 2. Середні значення параметра RMS для сімейства Daubechies (дані трьох тестованих суб'сктів)

\begin{tabular}{lcc|c|c}
\hline Indices & low & medium & high & average \\
\hline Db2 & 0.0362 & 0.0674 & 0.0998 & 0.0678 \\
Db3 & 0.0492 & 0.0659 & 0.1016 & 0.0722 \\
Db4 & 0.0502 & 0.0664 & 0.1008 & 0.0725 \\
Db5 & 0.0491 & 0.0664 & 0.1000 & 0.0418 \\
Db6 & 0.0491 & 0.0665 & 0.0980 & 0.0715 \\
Db7 & 0.0491 & 0.0660 & 0.0987 & 0.0712 \\
Db8 & 0.0491 & 0.0 .069 & 0.0999 & 0.0716 \\
Db9 & 0.0498 & 0.0661 & 0.0997 & 0.0718 \\
Db10 & 0.0492 & 0.0666 & 0.0985 & 0.0714 \\
Db11 & 0.0491 & 0.0663 & 0.0982 & 0.0712 \\
Db12 & 0.0490 & 0.0657 & 0.0991 & 0.0713 \\
Db13 & 0.0491 & 0.0658 & 0.0996 & 0.0715 \\
Db14 & 0.0492 & 0.0663 & 0.0991 & 0.0715 \\
\hline
\end{tabular}

RMS value, denoised power, and s.d. values for all wavelet functions suitable for biomedical signal processing with four levels of decomposition. Table 2 gives the results of collations of the average RMS value, while Table 3 gives the average MdF values of all chosen wavelet functions for three subjects at various muscle contraction force levels.

According to the results shown in Table 2, wavelet functions from the Daubechies family showed satisfactory performances; it should be noted that the wavelet function $\mathrm{db} 4$ showed a better performance value than other wavelet functions. This means that wavelet function db4 (from the average column in Table 2) is capable of denoising sEMG signals better than other wavelet functions of the same family.

Surface Myoelectric Signals. The RMS values were computed for each signal and all force data files, as this is the parameter that reflects more completely physiological correlates of the behavior of motor units during muscle contraction, and this has been termed as a "gold" standard for analyzing surface EMG signals. Since the wavelet function db4 shows the better performance for the results, it was considered the best for the EMG denoising process and further feature extractions. In order to make a reliable signal and muscle force determination, the knowledge on the effects of time-varying factors on the mean $(\mathrm{MnF})$ and median $(\mathrm{MdF})$ frequencies is very important. Two time-varying factors, muscular force and muscle geometry, are the major factors in the activities related to dynamic muscle contractions (muscle force and/or geometry are changing). The average values of the $\mathrm{MnF}$ and MdF of the signal-force data from three different subjects with different forces of muscle contraction are displayed in Tables 3 and 4 These data are an aggregate of all of the contractions performed by all subjects during the experiment.

Now, during a sustained constant-force contraction, the amplitude of the detected sEMG signal increases as a function of time. In fact, this phenomenon of myoelectric signal-force relationship approaches towards linearity with a considerable confidence for

T a b l e 3. Average median frequencies (MdF)) for diferent force levels (three subjects)

T а б л и ц я 3. Середні значення медіан частот $(\mathrm{MdF})$ для різних рівнів зусиль $(n=3)$

\begin{tabular}{lcc|c|c}
\hline \multicolumn{1}{c|}{ Values } & low & medium & high & average \\
\hline $\begin{array}{l}\text { median frequency } \\
\text { (raw) }\end{array}$ & 328.3 & 346.9 & 358.2 & 344.46 \\
$\begin{array}{l}\text { median frequency } \\
\text { (denoised) }\end{array}$ & 142 & 226.4 & 288.4 & 218.93 \\
\hline
\end{tabular}


T a b l e 4. Average mean frequencies(MnF) for different force levels

T а б л и ц я 4. Усереднені значення середніх частот (MnF) для різних рівнів зусиль

\begin{tabular}{l|c|c|c|c}
\multicolumn{1}{c}{ Values } & low & medium & high & average \\
\hline $\begin{array}{l}\text { mean frequency } \\
\text { (raw) }\end{array}$ & 337.8 & 355.4 & 364.4 & 352.53 \\
$\begin{array}{l}\text { mean frequency } \\
\text { (denoised) }\end{array}$ & 151.4 & 231.8 & 296.4 & 226.53 \\
\hline
\end{tabular}

the biceps brachii, i.e., increasing level in terms of the $\mathrm{MnF}$ and MdF.

Linear Discrimination Analysis. A purpose of discriminant function analysis is understanding of the dataset resulting from the procedure; this can give insight into the relationship between the group membership and the variables used to predict such membership. This approach has been used to investigate independent variable mean differences between the groups formed by the dependent variable and also to determine the percent of variance in the dependent variable explained by the independents over and above the variance accounted for by control variables, using sequential discriminant analysis.

Discriminant function analysis is broken into a two-step process: (i) testing significance of a set of discriminant functions, and (ii) classification.

First, the Wilks' lambda is used to test if the discriminant model as a whole is significant or not. It is the ratio of within-group sums of squares to the total sums of squares. This is the proportion of the total variance in the discriminant scores not explained by the differences among groups. Second, if the F test shows the significance, the individual independent variable is assessed to see if it differs significantly from the group mean, and these are used to classify the dependent variable. The lambda varies from 0 to 1 , with 0 meaning that the group means differ from each other, and 1 meaning that all group means are the same. The associated significance value indicates whether the difference is significant. In our case, the Wilks' lambda of 0.376 had a significant value
$(P=0.012)$; thus, the group means appear to differ from each other. The associated $\chi^{2}$ statistic (6.354) tests the hypothesis that the means of the functions listed are equal across groups. The relatively small significance value ( $P$ value) indicates that the discriminant function does better than chance at separating the groups. Since the value of $P<0.05$, it can be concluded that the model is a good fit for the data significance.

Now, as we are interested in the relationship between a group of the independent variables and one categorical variable, it would be beneficial to know how many dimensions we would need to express this relationship. Using such relationship, we can predict a classification based on the independent variables or assess how well the independent variables separate the classification categories. The larger the Eigen value ( 0.376 in our study), the more the variance in the dependent variable is explained by this function. The canonical correlation $(0.790)$ is the measure of association between the discriminant function and the dependent variable. The square of the canonical correlation coefficient is the percentage of the variance explained in the dependent variable. Finally, the classification table (also called a prediction matrix or table) used to assess the performance of the model is shown in Table 5. It helps to describe a simple summary of the number and percent of subjects classified correctly and incorrectly.

Table 5 gives information about the actual group membership. So, it is concluded that the overall percentage of correct classification is $88.90 \%$

T a b l e 5. Linear discrimination analysis: classification results

Т а б л и ц я 5. Результати класифікації за допомогою лінійного дискримінантного аналізу

\begin{tabular}{|c|c|c|c|c|c|}
\hline & \multirow{2}{*}{ Values } & \multirow{2}{*}{ output } & \multicolumn{2}{|c|}{ predicted group membership } & \multirow{2}{*}{ total } \\
\hline & & & 0 & 1 & \\
\hline \multirow{4}{*}{ Original } & \multirow{2}{*}{ Count } & 0 & 6 & 0 & 6 \\
\hline & & 1 & 1 & 2 & 3 \\
\hline & \multirow{2}{*}{$\%$} & 0 & 100.0 & 0.0 & 100.0 \\
\hline & & 1 & 33.3 & 66.7 & 100.0 \\
\hline
\end{tabular}


Looking at the columns in Table 5 instead of the rows, one can also calculate the positive probability value:

(i) Positive probability value gives the confidence in the predicted results. A higher probability means that there is a high enough chance that a predicted model will actually be significant $(85.71 \%)$.

(ii) The specificity is the percentage of correct classification predicted in the model (100.0\%).

(iii) The sensitivity is the percentage of the model correctly predicted $(66.70 \%)$.

Finally, the best average classification result calculated for the db4 wavelet family after applying linear discrimination analysis is $88.90 \%$, whereas the worst classification result calculated for $\mathrm{db} 5$ is $77.80 \%$.

Data Statistical Method. We were interested in refining the experiment to increase its sensitivity for detecting differences in the dependent variables. An effective step to achieve better performance for the classification of signals recorded at different voluntary contractions is extraction of a feature from the raw data before performing the analysis of multiple activities. The analysis of extracted features further helps to identify the significance of the sEMG-muscular force relationship existing between these phenomena in voluntary contractions.

To further extend the study of relational interpretations of selected operations of the arm, a statistic technique of analysis of variance of both experimental and reconstructed data was implemented for interpretation of the signal class separability in order to identify the best sEMG signal amplitude for different voluntary contractions optimum with respect to establish the best myoelectric signalforce relationship. So, to appreciate the classification of the arm motions for multiple samples, one-way analysis of variance with prior comparison has been implemented. The analysis of variance (ANOVA) with three independent groups related to the biceps and presenting the raw, detailed, and approximated wavelet coefficients is shown in Tables 6 and 7.

The basic procedure in this case is to derive two different estimates of the variance from the data; then, the ratio of these two estimates is calculated. One of these estimates (SSB) is a measure of the effect of the independent variable combined with the error variance, while another estimate (SSW) characterizes the error variance itself. Then, a significant $F$ ratio among two estimates is calculated. The significant $\mathrm{F}$ ratio indicates that the population means are, probably, not all equal to each other. Since the estimate of data for the sum of squares between the groups (SSB, 0.2736, 0.2688 ) is large compared to the data for within the group (SSW, 0.01, 0.0046). It is concluded that the test statistic is significant at this level. The mean

T a b l e 6. Analysis of the variance results for biceps voluntary contractions (raw)

Т а б л и ц я 6. Результати аналізу варіанси для довільних скорочень біцепса (первинні дані)

\begin{tabular}{|c|c|c|c|c|c|c|}
\hline Source of variation & Sum of squares & (dof) & mean square & Fisher's ratio $(\mathrm{F})$ & $P$ & critical value (fc) \\
\hline Sum of between-group squares & 0.273 & 2 & 0.212 & 82.08 & 0.0001 & 5.14 \\
\hline Sum of within-group squares & 0.01 & 6 & 0.006 & & & \\
\hline Total sum of squares & 0.283 & 8 & & & & \\
\hline
\end{tabular}

T a b l e 7. Analysis of the variance results for triceps voluntary contractions (raw)

Т а б л и ц я 7. Результати аналізу варіанси для довільних скорочень трицепса (первинні дані)

\begin{tabular}{|c|c|c|c|c|c|c|}
\hline Source of variation & Sum of squares & (dof) & mean square & Fisher's ratio $(\mathrm{F})$ & $P$ & critical value (fc) \\
\hline Sum of within-group squares & 0.004 & 6 & 0.0007 & & & \\
\hline
\end{tabular}


square error of sEMG signals helps to evaluate the quality of the robustness function. The performance of algorithms is the best when the mean square error has the smallest value. Here, the mean square error (MSE) values within the group are 0.0060 and 0.0007 for the biceps and triceps muscles, respectively, which means that the sEMG signal contains useful information, and undesirable parts of the signals are removed.

The $F$ ratio [18] is the statistic used to test the hypothesis that the effects are real; in other words, that the means significantly differ from each other. There is a significant difference in the amplitude gain across different motions, $F(2,6)=82.086$, $P<0.05, \mathrm{~F}(2,6)=175.3$ with the raw data for the biceps and triceps muscles for three independent voluntary contractions, respectively. From the Tables, we can see that the $\mathrm{F}$ ratio is greater than the critical value (fc) in all cases; so the means are significantly different, and it is concluded that there is a more significant difference between the groups (SSB) than that within the groups (SSW). For both samplings of the experimental data, analysis of variance revealed the continuous significant differences over time, which means that this technique is useful for revealing differences in the shape and magnitude of sEMG signals for independent motions. Thus, analysis of the variance found statistical differences between electrode positions $(P<0.05)$, between surface electrode conditions, and for interaction between all groups.

\section{DISCUSSION}

Wavelet denoising was applied to ensure the effectiveness of sEMG signals at various static voluntary contractions of the elbow-controlling muscles, since it provides better time and frequency resolution simultaneously for the analysis of nonstationary signals. During our study, five basic parameters were extracted by analyzing the signal amplitude corresponding to different voluntary contractions, but the appropriate wavelet has been chosen on the basis of the RMS and s.d. values. The raw sEMG signals were used to calculate the RMS and s.d. values for all wavelets suitable for signal processing with four levels of decomposition.

Further analysis of variance (ANOVA) as a novel approach for revealing differences in the shape and magnitude of EMG signals for multiple motions is implemented. The $P$ values for biceps and triceps $\mathrm{F}(2,6)$ is 0.0001 that is much smaller than 0.05 . So, the null hypotheses of equal means is rejected, and, finally, the test statistic is significant. The assessment of the muscle force relation with sEMG signals can be applied to a wide class of daily used applications. Although the behavior of $\mathrm{MnF}$ and $\mathrm{MdF}$ is similar, the value of the time domain mean frequency is slightly greater than the time domain median frequency because of the skewed shape of the sEMG power spectrum. In addition, both mean and median features can be considered universal indices to identify all factors, including muscle geometry, muscular force, and voluntary contraction. To summarize:

(i) The surface myoelectric signal-force relationship is primarily determined by different muscle geometries including electrode configuration, fibre diameter, subcutaneous tissue thickness, etc.;

(ii) The electrode locations (interelectrode distance of about $1 \mathrm{~cm}$ ) over the muscle were changed during the experiment;

(iii) The mean $(\mathrm{MnF})$ and median $(\mathrm{MdF})$ frequency parameters are linear for the biceps and triceps brachii muscles, with the amplitude of the myoelectric signal increasing linearly with the force exhibited;

(iv) The one-way analysis of variance (ANOVA) approach for comparing the ability of variations in sEMG signals for maximum class separability has been identified;

(v) The classification accuracy of $88.90 \%$ has been achieved for upper limb class separability movements.

Acknowledgement. The author is grateful to Dr. Amod Kumar and Dr. Ravinder Agarwal, PhD supervisors for helping in writing this paper.

All procedures followed were in accordance with the ethical standards of the responsible Committees on human experimentation (institutional and national) and with the Helsinki Declaration of 1975, as revised in 2000 (5). Written informed consent was obtained from all subjects for being included in the study.

The author, V. Karan, confirms the absense of any conflict related to comercial or financial interests and to interrelations with organizations or persons in any way involved in the research.

\section{B. $\operatorname{KapaH}^{1}$}

КЛАСИФІКАЦІЯ ЕЛЕКТРОМІОГРАФІЧНИХ СИГНАЛІВ З ВИКОРИСТАННЯМ АНАЛІЗУ АNOVА, БАЗОВАНА НА ВЕЙВЛЕТ-ПЕРЕТВОРЕННЯХ

\footnotetext{
${ }^{1}$ Університет Тхапар, Патіала (Індія).
} 
Р е $з$ ю м е

Досліджували можливість застосування вейвлет-аналізу щодо сигналів поверхневої електроміограми (пЕМГ). Використання видалення шумів із записів пЕМГ перед обробкою таких сигналів для подальшого аналізу є дуже істотним. Сигнали пЕМГ оцінювалися в наступній послідовності: спочатку отриманий сигнал підлягав декомпозиції з використанням вейвлет-перетворення, потім декомпозовані коефіцієнти аналізувались із застосуванням порогових методик, i, нарешті, виконувалася реконструкція. Попередньо порівнювали ефективність видалення шумів у межах вейвлет-сімейства Daubechies. Було встановлено, що вейвлет-перетворення db4 із цього сімейства виконує знешумлення найкращим чином. Отримані результати вказують на те, що вейвлет-сімейства Daubechies $\epsilon$ більш придатними для аналізу пЕМГ сигналів, отриманих в умовах реєстрації різних моторних реакцій м'язів верхніх кінцівок; досягалася точність класифікації 88.9 \%. Потім статистична методика (однобічний повторний факторіальний аналіз) застосовувалася щодо експериментальних коефіцієнтів для встановлення якості розділення даних при різних рухах.

\section{REFERENCES}

1. J. Kilby and H. G. Hosseini, "Extracting effective features of SEMG using continuous wavelet transform," Conf. Proc. IEEE Eng. Med. Biol. Sci., 1, 1704-1707 (2006).

2. H. S. Ryait, A. S. Arora, and R. Agarwal, "Interpretations of wrist operations from surface-EMG signals at different locations on arm along with acupressure points," IEEE Transact. Biomed. Circ. Syst., 4, No. 2, 101-111 (2010).

3. Q. Zhang and Zh. Luo, "Wavelet de-noising of electromyography," in: Proc. IEEE Internat. Conf. Mechatron. Automat. (June 25 - 28, 2006), China (2006), pp. 1553-1558.

4. K. A. Wheeler, H. Shimada, D. K. Kumar, and S. P. Arjunan, "A sEMG model with experimentally based simulation parameters," Conf. Proc. IEEE Eng. Med. Biol. Soc., 42584261 (2010).

5. N. M. Sobahi, "Denoising of EMG signals based on wavelet transform," Asian Transact. Eng., 1, No. 5, 17-23 (2011).

6. A. Phinyomark, A. Nuidod, P. Phukpattaranont, and C. Limsakul, "Feature extraction and reduction of wavelet transform coefficients for EMG pattern classification," Electron. Electr. Eng. Signal Technol., 6, 27-32 (2012).

7. A. Phinyomark, C. Llimsakul, and P. Phukpattaranont, "Optimal wavelet functions in wavelet denoising for multifunction myoelectric control," ECTI Transact. Electr. Eng. Electron. Commun., 8, 43-52 (2010).

8. A. Phinyomark, C. Llimsakul, and P. Phukpattaranont, "Application of wavelet analysis in EMG feature extraction for pattern classification," Measur. Sci. Rev., 11, 45-52 (2011).

9. K. Englehart, B. Hudgins, and P. A. Parker, "A wavelet-based continuous classification scheme for multifunction myoelectric control," IEEE Transact. Biomed. Eng., 48, No. 3, 302-311 (2001).

10. M. Lascu and D. Lascu, "Graphical programming based biomedical signal acquisition and processing," Int. J. Circ. Syst. Sign. Proc., 1, No. 4, 317-326 (2007).

11. R. L. Ortolan, R. N. Mori, R. R. Pereira, et al., "Evaluation of adaptive/nonadaptive filtering and wavelet transform techniques for noise reduction in EMG mobile acquisition equipment," IEEE Transact. Neural Syst. Rehabil. Eng., 11, No. 1, 60-69 (2010).

12. C. F. Jiang and S. L. Kuo, "A comparative study of wavelet denoising of surface electromyographic signals," Conf. Proc. IEEE Eng. Med. Biol. Sci., 1868-1871 (2007).

13. X. Zhang, Y. Wang, and R. P. S. Han, "Wavelet transform theory and its application in EMG signal processing," 7th Int. Conf. Fuzzy Syst. Knowl. Discov. (Aug 23-26, 2010), 6 (2010).

14. S. Micera, "Control of hand prostheses using peripheral information," IEEE Rev. Biomed. Eng., 3, 48-68 (2010).

15. K. Englehart, B. Hudgins, P. A. Parker, and M. Stevenson, "Classification of the myoelectric signal using time-frequency based representations," Med. Eng. Phys., 21, Nos. 6/7, 431-438 (1999).

16. A. Phinyomark, P. Phukpattaranont, C. Limsakul, et al., "The usefulness of mean and median frequencies in electromyography analysis," in: Computational Intelligence in Electromyography Analysis - A Perspective on Current Applications and Future Challenges, G. R. Naik (ed.), InTech, Chap. 8 (2012).

17. C. J. De Luca, M. A. Sabbahi, and S. H. Roy, "Median frequency of the myoelectric signal: Effect of hand dominance," Eur. J. Appl. Physiol. Occup. Physiol., 55, No. 5, 457-464 (1986).

18. Sh. J. Coakers, SPSS Version 12.0 for Windows, Analysis Without Anguish, John Wiley Sons Publ., Australia (2005), p. 88 . 